Modern Asian Studies 55, 2 (202I) pp. 552-586. (C) The Author(s) 2020. Published by

Cambridge University Press. This is an Open Access article, distributed under the terms of the Creative Commons Attribution licence (http://creativecommons.org/licenses/by/4.o/ ), which permits unrestricted re-use, distribution, and reproduction in any medium, provided the original work is properly cited.

doi:Io.Ior7/Soo26749XIgooo337 First published online o6 May 2020

\title{
Trans-Imperial Anarchism: Cooperatist communalist theory and practice in imperial Japan*
}

\author{
ROBERT KRAMM
}

School of History, LMU Munich

Email:robert.kramm@lrz.uni-muenchen.de

\begin{abstract}
This article investigates anarchist theory and practice in I920s and I930s imperial Japan. It deliberately focuses on concepts and interventions by a rather unknown group - the Nōson Seinen Sha - to highlight a global consciousness even among those anarchists in imperial Japan who did not become famous for their cosmopolitan adventures. Their trans-imperial anarchism emerged from a modern critique of the present and engagement with cooperatist communalist ideas and experiences in Asia, Russia, and Western Europe. Anarchists theorized and implemented new forms of living that challenged the forces of capitalism, imperialism, and increasing militarism. In doing so, they simultaneously positioned themselves against established conservative and fascist agrarianism as well as Marxist dogmatism in the socialist movement. Despite their repression by the imperial state, they offered a radical, universalist, yet pragmatic way of being in autarkic farming village communes that corresponded with similar ideas and movements worldwide.
\end{abstract}

\section{Introduction}

Anarchism has been a global phenomenon. Anarchist theory and practice have had the global aim of liberation, through overcoming capitalism and state power as well as any other form of authority, hierarchy, and

* I am grateful to Cyrian Pitteloud, Pascale Siegrist, Narita Keisuke, Sho Konishi, Shakhar Rahav, Umemori Naoyuki, Carl Levy, Harriet Hulme, and the anonymous reviewers of Modern Asian Studies for their insightful comments which helped tremendously to improve this article. 
exploitation. Its vision is to allow people to govern themselves autonomously without coercion, based on individual freedom and mutually shared interests. Most anarchists, anarchist thought, and anarchist movements worldwide have been embedded within networks that cross national, imperial, and regional borders, yet they have been simultaneously intertwined with local and historically specific contacts and contexts. For the late nineteenth and early twentieth centuries, in particular, Benedict Anderson has mapped 'the gravitational force of anarchism', demonstrating how dissidents at the margins of empire appropriated and used the new, accelerated, and also accessible, means of travelling and publishing for their revolutionary cause. Of course, many anarchist projects in various regions of the world have been part of a longer history of statelessness, undermining the hegemonic notion of state administration as the only modern historic form. ${ }^{2}$ For other (mostly non-European) countries and colonies, at a time when the whole world was affected by capitalism, imperialism, and colonialism, anarchism evolved as a new and attractive political theory and practice for anti-authoritarian and anti-colonial social movements. Studies on the Indian anti-colonial Ghadar movement and networks in the Eastern Mediterranean, for instance, have unearthed the global connections of activist groups by tracking the trails of non-white radicals who travelled the world in their anti-colonial struggle. ${ }^{3}$ Worldwide anarchism was grounded in anarchist networks that 'comprised of formal and informal structures, [...] facilitated doctrinal diffusion, financial flows, transmission of information and symbolic practices, and acts of solidarity', as Lucien van der Walt and Steven Hirsch have convincingly argued. ${ }^{4}$ Despite local variations,

\footnotetext{
${ }^{1}$ Benedict Anderson, Under Three Flags: Anarchism and the Anti-Colonial Imagination (New York: Verso, 2007), p. 2.

${ }^{2}$ A prominent case study for Southeast Asia and beyond is James C. Scott, The Art of Not Being Governed: An Anarchist History of Upland Southeast Asia (New Haven: Yale University Press, 2009).

${ }^{3}$ Maia Ramnath, Haj to Utopia: How the Ghadar Movement Charted Global Radicalism and Attempted to Overthrow the British Empire (Berkeley: University of California Press, 201 I); and Ilham Khuri-Makdisi, The Eastern Mediterranean and the Making of Global Radicalism, I860I9I4 (Berkeley: University of California Press, 2010).

${ }^{4}$ Lucien van der Walt and Steven J. Hirsch, 'Rethinking Anarchism and Syndicalism: The Colonial and Post-colonial Experience, I870-1940', in Anarchism and Syndicalism in the Colonial and Postcolonial World, I870-1940: The Praxis of National Liberation, Internationalism, and Social Revolution, (eds) Steven J. Hirsch and Lucien van der Walt (Leiden: Brill, 20Iо), p. li.
} 
anarchist theory and practice were undeniably significant and globally connected - in Asia and beyond. ${ }^{5}$

In the case of imperial Japan, despite prevailing stereotypes of the alleged obedience of the Japanese people, scholars have also highlighted Japan's rich tradition of anarchism. Arguably the most prominent Japanese anarchists, Kōtoku Shūsui (I87I-IgII) and Ōsugi Sakae (I885I923) elaborated highly sophisticated analyses and critiques of capitalism and imperialism; in doing so, they looked beyond Japan with a global vision and integrated the Japanese empire into the world system. ${ }^{6}$ Classical studies have debated to what extent their critique was grounded in their experiences abroad, underscoring, for instance, how Kōtoku, Ōsugi, and other anarchists were influenced by ideas such as Christian socialism and how much they contributed to anarchist theory and practice in Japan. ${ }^{7}$ More recent scholarship highlights bordercrossing networks that operated in multiple directions, with sometimes contingent circumstances that contributed significantly to the development of anarchism in East Asia. By exploring the routes of anarchist Ishikawa Sanshirō (I876-I956), Nadine Willems has shown that highly mobile individuals built networks that shaped 'ideas of social change' by crossing imperial Japan's borders. ${ }^{8}$ Studies focusing on Korean and Chinese students who received their education in Japan and returned to Korea and China similarly underscore the building of anarchist networks beyond the borders of imperial Japan and

\footnotetext{
${ }^{5}$ The historical and thematic variety of anarchism in theory and practice globally is also vividly illustrated in: Carl Levy and Matthew S. Adams (eds), The Palgrave Handbook of Anarchism (London: Palgrave Macmillan, 2019).

${ }^{6}$ On Kōtoku and Ōsugi, respectively, see: Robert Thomas Tierney, Monster of the Twentieth Century: Kōtoku Shūsui and Japan's First Anti-Imperialist Movement (Oakland: University of California Press, 2015); and Naoyuki Umemori, Shoki shakai shugi no chikeigaku: Ōsugi Sakae to sono jidai (Tokyo: Yūshisha, 2016).

${ }^{7}$ See, among others, Stephen S. Large, 'The Romance of Revolution in Japanese Anarchism and Communism during the Taishō Period', Modern Asian Studies, vol. i I, no. 3, I977, pp. 44I-467; Fred G. Notehelfer, Kōtoku Shūsui: Portrait of a Fapanese Radical (London and New York: Cambridge University Press, I97I); Michio Matsuda, Anakizumu: Henshū, kaisetsu, Gendai nihon shisō taike ı6 (Tokyo: Chikuma shobō, ı963), pp. 36-42; Thomas A. Stanley, Ōsugi Sakae: Anarchist in Taishō Japan. The Creativity of the Ego (Cambridge, MA: Harvard University Press, I982), pp. 59-63; Germaine A. Hoston, The State, Identity, and the National Question in China and Fapan (Princeton: Princeton University Press, I994), p. I27.

${ }^{8}$ Nadine Willems, 'Transnational Anarchism, Japanese Revolutionary Connections, and the Personal Politics of Exile', The Historical Fournal, vol. 6r, no. 3, 2018, pp. 71974I, p. $72 \mathrm{I}$
} 
throughout East Asia. ${ }^{9}$ Indeed, studies on anarchist movements in Japan and other parts of the world have demonstrated that the mobility and contacts of anarchist and other radical activists in transnational networks - whether in the form of study groups, labour unions, and publishing collectives - facilitated the impact of the movement. ${ }^{10}$

Although this article builds on these insights, it explores the global or, more precisely, the trans-imperial connectedness of anarchism in imperial Japan from a different angle. It analyses a set of writings from an anarchist communist group called Nōson Seinen Sha (Farming Village Youth Association) in the late I920s and early i93os. The Nōson Seinen Sha was a rather small and socially diverse group of anarchists. Its most prominent members were probably Miyazaki Akira (I900-I977) and Suzuki Yasuyuki (1903-1970). The group aimed at building a libertarian society by establishing autarkic, cooperatist, communalist farming villages that were independent of state power, the capitalist market, and imperialist expansion. It started its project on the outskirts of Nagano prefecture in 193I. This article deliberately focuses on one such local group to underscore the global dimension of imperial Japan's anarchist thought, even among those proponents who did not become famous for their extensive cosmopolitan adventures. It uses trans-imperialism as a perspective that acknowledges the early twentieth century as a historical moment when, in Japan as elsewhere, empiresand not the nation-state - were the predominant framework of socio-political organization. ${ }^{11}$ Even fascism, arguably the most nationalistic contemporary global current, which is usually perceived as being solely preoccupied with centring itself in the world, 'subsumed imperialism ... and took over processes and institutions that originated

\footnotetext{
${ }^{9}$ Dongyoun Hwang, Anarchism in Korea: Independence, Transnationalism, and the Question of National Development 1919-1984 (Albany: State University of New York Press, 2016); Rebecca Karl, Staging the World: Chinese Nationalism at the Turn of the Twentieth Century (Durham and London: Duke University Press, 2002); Arif Dirlik, Anarchism in the Chinese Revolution (Berkeley: University of California Press, 199I); and Peter Zarrow, Anarchism and Chinese Political Culture (New York: Columbia University Press, 1990).

${ }^{10}$ Davide Turcato, 'Italian Anarchism as a Transnational Movement, I885-1915', International Review of Social History, vol. 52, no. 3, 2007, pp. 404-444, pp. 412 and 415; Ken C. Kawashima, The Proletarian Gamble: Korean Workers in Interwar Fapan (Durham and London: Duke University Press, 2009).

${ }^{11}$ Daniel Hedinger and Nadin Heé, 'Trans-Imperial History-Connectivity, Cooperation and Competition', fournal of Modern European History, vol. ı6, no. 4, 2018, pp. $429-45^{2}$.
} 
outside, or prior to, its own historical moment'. ${ }^{12}$ As Jane Burbank and Frederick Cooper have put it, 'empires and their interactions shaped the context in which people gauged their political possibilities, pursued their ambitions, and envisioned their societies'. ${ }^{13}$ That said, despite the multiple forms of systematic exploitation, discrimination, and violence inherent to them, empires were also framing the channels of communication and room-to-manoeuvre of its dissidents. Trans-imperial anarchism acknowledges this historical moment and indicates that anarchists' struggle against state authority targeted an imperial state, which they wanted to overcome. Their vision of liberation and solidarity with oppressed people was global and reached beyond Japan's imperial boundaries into other imperial formations. Moreover, Japanese anarchists experienced peculiar circumstances: they were confronted with a repressive authoritarian regime, but also found themselves in a 'double bind' situation in which they were simultaneously subjugated to Western hegemony yet were themselves positioned within a non-white imperial centre. ${ }^{14}$ Imperial Japan's anarchists' radical analysis, critique, and solutions to their immediate historical situation; the tension between the West and non-West that emerged in Japanese anarchists' critical reading of revolutionary theory; as well as their appreciation and discussion of non-Western cooperatist communalist concepts are at the centre of this article. Trans-imperial anarchism thus means anarchists fighting to overthrow imperial state authority as well as crossing imperial borders by reading, criticizing, and speaking about anarchist theory and practice in imperial formations outside the Japanese empire, while simultaneously navigating within and beyond the imperial boundaries of their own historical moment and position.

The article begins by placing the Nōson Seinen Sha within Japan's anarchist movement and introduces the group's understanding of

${ }^{12}$ Reto Hofmann, 'The Fascist New-Old Order', fournal of Global History, vol. I2, no. 2, 2017, pp. I66-I83, pp. I72-I73; see also the special issue's editorial: Daniel Hedinger and Reto Hofmann, 'Axis Empires: Towards a Global History of Fascist Imperialism', Journal of Global History, vol. I2, no. 2, 20I7, pp. I6I-I65; and Harry D. Harootunian, Marx after Marx: History and Time in the Expansion of Capitalism (New York: Columbia University Press, 2015).

${ }^{13}$ Jane Burbank and Frederick Cooper, Empires in World History: Power and the Politics of Difference (Princeton: Princeton University Press, 20I0), pp. 3-4.

${ }^{14}$ Nadin Heé, Imperiales Wissen und koloniale Gewalt: Fapans Herrschaft in Taiwan I895-1945 (Frankfurt/M.: Campus, 2012), p. 30; Sven Saaler, 'Pan-Asianism in Modern Japanese History: Overcoming the Nation, Creating a Region, Forging an Empire', in Pan-Asianism in Modern Fapanese History: Colonialism, Regionalism and Borders, (eds) Sven Saaler and Victor Koschmann (New York: Routledge, 2007), pp. I-I8. 
cooperatist communalism and its vision of a better future. The next section integrates the Nōson Seinen Sha into the historical context of early twentieth-century imperial Japan's agrarianist discourse. Along with the writings of the Nōson Seinen Sha, the article illustrates the group's radical criticism and concepts of cooperatist communalism, which includes underscoring its embrace of science, such as an anarchist reading of evolutionary theory and social organization as the basis for its analysis and critique. This demonstrates that anarchism, all-too-often disqualified as being primitive, anti-modern, irrational, and anti-science, could very well be grounded in scientific reasoning and develop a concise revolutionary theory and practice. ${ }^{15}$ Finally, the article puts imperial Japanese anarchist thought around cooperatist communalism into conversation with radical utopian community projects in other imperial settings in Asia. Unfortunately, farmers' responses to the Nōson Seinen Sha's engagement are not documented and thus their voices are silent in this article. ${ }^{16}$ Yet the Nōson Seinen Sha's texts stress the trans-imperial, indeed global, scope of its theory and practice. Its analysis of the historical moment and its own position, its acknowledgement of revolutionary movements and thought worldwide, and its contribution to a global struggle all developed within a 'global consciousness'. Such consciousness, as Sebastian Conrad and Dominik Sachsenmaier have argued, was fostered by educated metropolitan elites initiating global channels of communication in the late nineteenth century. The circulation of knowledge through newspapers and journals, for instance, constituted a new way of perceiving the world. This does not necessarily mean that every reported event was of global importance, but that a global consciousness 'affected a general mentality', which 'also framed the context in which specific political measures were discussed'. ${ }^{17}$ Half a century later, this also applied to Japanese anarchist circles. Cooperatist communalist thought and practice in imperial Japan resonated with similar global ideas and movements, ranging from anarchist communes to intentional

\footnotetext{
${ }^{15}$ For a thorough discussion - and critique - of anarchism's alleged lack of complexity, see: Nathan Jun, Anarchism and Political Modernity (New York: Continuum Books, 2012).

${ }^{16}$ Farmers, believed to be the main revolutionary subjects, were the main targets of the group's agitation.

${ }^{17}$ Sebastian Conrad and Dominik Sachsenmaier (eds), Competing Visions of World Order: Global Moments and Movements, I880s-1930s (New York: Palgrave Macmillan, 2007), p. I4.
} 
communities, vegetarian colonies, and socialist kibbutzim. ${ }^{18}$ This was not a coincidence. The members of the Nōson Seinen Sha were well aware of what was going on in the world and were not passive recipients of a trans-imperial flow of knowledge. Rather, they selectively appropriated and commented on this knowledge, and used it to their own ends, confident of the significance of their contribution to a global struggle for liberation.

\section{Anarchism, cooperatist communalism, and the emergence of the Nōson Seinen Sha}

Forming a prominent movement in the early twentieth century, Japanese anarchists were important mediators of knowledge and contributed tremendously to the intellectual environment in imperial Japan. Anarchist thought was widely circulated in numerous radical newspapers and journals, such as the Heimin Shinbun and Kindai Shisō, but also through translations of literary and scientific works. ${ }^{19}$ State authorities were eager not to miss any opportunity to repress the distribution of anarchist knowledge by shutting down newspapers and repeatedly harassing and arresting its editors. ${ }^{20}$ In particular, in the wake of the Public Security Preservation Law of 1925 , state repression severely weakened Japan's anarchist movement. ${ }^{21}$ Nevertheless,

${ }^{18}$ On the different, yet similar, communal projects the world over, see: Tessa Morris-Suzuki, 'Beyond Utopia: New Villages and Living Politics in Modern Japan and across Frontiers', History Workshop fournal, vol. 85, 2018, pp. 47-71; Shakhar Rahav, 'How shall we Live?: Chinese Communal Experiments after the Great War in Global Context', fournal of World History, vol. 26, no. 3, 2016, pp. 521-548; Antony Taylor, "Septic Edens": Surveillance, Eroticized Anarchy and "Depraved Communities" in Britain and the Wider World, I890-1930', in Global Anti-Vice Activism: Fighting Drinks, Drugs and 'Immorality', I890-1950, (eds) Jessica R. Pliley, Robert Kramm and Harald Fischer-Tiné (Cambridge and New York: Cambridge University Press, 2016), pp. 53-73; and Lyman Tower Sargeant, Utopianism: A Very Short Introduction (Oxford: Oxford University Press, 2010).

${ }^{19}$ This larger argument of anarchist knowledge production and circulation, particularly through translations, is based on Sho Konishi, Anarchist Modernity: Cooperatism and Fapanese-Russian Intellectual Relations in Modern Fapan (Cambridge, MA: Harvard University Press, 2013).

${ }^{20}$ John Crump, Hatta Shūzō and Pure Anarchism in Interwar Fapan (New York: St. Martin's Press, 1993), p. $3^{2}$.

${ }^{21}$ An overview of Japan's anarchist movement and the waves of state repression against its proponents is provided by Ryūji Komatsu, Nïhon anakizumu undōshi (Tokyo: Aoki shinsho, 1972). 
Japanese anarchists were able to maintain publication collectives, study groups, and activist associations. Between the rgoos and I930s, various anarchist individuals and groups within the very heterogenous anarchist movement developed their own strategies of dodging, undermining, and overcoming state repression and authority. Anarchist terrorism and anarchist syndicalism were two distinctive strands of the movement that were eager to bring about instant social revolution. The Girochinsha (Guillotine Society) was probably the most prominent group promoting anarchist terror, through the bombing of symbols and killing of members of the imperial state. Its attempts at attacking the system, however, were unsuccessful, particularly in face of the sheer superior force of imperial Japan's police and military. ${ }^{22}$ Its members Furuta Daijirō and Nakahama Testu, for example, were hanged for their intention to and preparations made to assassinate then Crown Prince Hirohito in the early I920s. $^{23}$ Syndicalism, which focused on union building and a general strike of the organized labour force in Japan's emerging industrial sector, had appealed to workers since Japan's early industrialization in the late nineteenth century and had become much more popular. ${ }^{24}$ Its popularity also derived from the fact that solidarity with the growing number of industrial workers promised protection for the anarchist movement and created an awareness of collective strength. Moreover, anarchist-syndicalists believed that mobilizing the industrial masses would bring political leverage, because workers' strikes and sabotage taking place in factories affected the industrial sector, which was 'vital to the state's military and economic ambitions'. ${ }^{25}$

Anarchist communists, a third strand of anarchism in imperial Japan, among whom the Nōson Seinen Sha was numbered, particularly opposed anarchist syndicalism. They argued that syndicalism - as well as political-party building and parliamentarianism - would eventually produce new hierarchies. Moreover, they also believed that syndicalism was preoccupied with the life worlds of workers in imperial Japan's

${ }^{22}$ Michiaki Asaba, Anākizumu: Meicho deta dor nihon shisō nyūmon (Tokyo: Chikuma Shinsho, 2004), pp. 6I-62.

${ }^{23}$ Hélène Raddeker has integrated anarchist terrorism, with its fatal and tragic moments, in a longer tradition of twentieth-century Japanese radicalism that often evolved around themes of vengeance and martyrdom. Hélène Bowen Raddeker, Treacherous Women of Imperial Japan. Patriarchal Fictions, Patricidal Fantasies (New York: Routledge, 1997), p. I31.

${ }^{24}$ Shintarō Hagiwara, Nìhon anakizumu rōdō undōshi (Tokyo: Gendai Shichosha, I969).

${ }^{25}$ Crump, Hatta Shūzō, p. 33 . 
industrial and urban centres, and ignored the majority of people who were still subsisting on farms in the countryside. Anarchist communists, also referred to as 'pure anarchists', propagated cooperatist communalism and proposed a much more fundamental break with the remains of feudalism in the agrarian sector. This would also undermine capitalist modes of production by establishing cooperative farming within a libertarian society. ${ }^{26}$ Based on the conviction that the countryside was the main arena of social revolution, anarchists such as Ishikawa Sanshirō, and also the Nōson Seinen Sha, articulated very progressive notions of human existence, interaction, and organization that would evolve in anarchist farming communes. ${ }^{27}$

Anarchist communist theory and practice were grounded in cooperatist communalism. In the American context, Murray Bookchin has commented extensively on communalism's aim to conceptualize a libertarian, federalist system of autonomously organized municipalities that allow people a self-determined life. Communalism, a term originating from the Paris Commune of i871, 'does not focus [on] the factory as its principle social arena or on the industrial proletariat as its main historical agent; and it does not reduce the free community of the future to a fanciful medieval village'. ${ }^{28}$ Rather, communalism circumscribes a democratic organization, often in form of farming villages and cooperatist workshops, that is not interested in political and economic structures alone, but equally aims at cultural production and social relations 'according to the cannons of reason, reflection, and discourse that uniquely belong to our species'. ${ }^{29}$ Cooperation (that is, human beings assisting each other) is a key characteristic of communalism and implies the necessity of practice and human agency.

In imperial Japan, cooperatist communalism incorporated anarchist communists and their conception of voluntary cooperative associations in communal village projects that would challenge established forms of exploitation and oppression. Anarchist communists such as the Nōson Seinen Sha referred to farming villages as nōson, quite similarly to other contemporary critics of capitalism, industrialization, and urbanization from different political strands. Yet they clearly distanced themselves

\footnotetext{
${ }^{26}$ Ibid., pp. IOI-IO3.

${ }^{27}$ Taku Nishiyama, Ishikawa Sanshirō no yūtopia: Shakai shisō to jüssen (Tokyo: Tōjishobō, 2007).

${ }^{28}$ Murray Bookchin, Social Ecology and Communalism (Oakland, CA: AK Press, 2006), pp. $89-99$.

${ }^{29}$ Ibid., p. 80.
} 
from conservative and fascist notions of countryside farming life as well as from anarcho-syndicalism's focus on industrial labour, criticizing them for the exploitation of both farmers and the countryside for the benefit of the industrializing urban centres. They conceived of cooperatively owned farming villages, shared means of production, and autarky as initiating a communal life in the museifu konmyun (anarchist commune), which they considered the fundamental basis on which to build a communal, cooperative society (kyōdo shakai). Mutual aid (sōgo fujo), in Peter Kropotkin's sense, Japanese anarchists argued, was the overarching force that would tie communal life together. Hence, cooperatist communalism was more than a cooperative farming association as it aimed at a holistic way of being so as to improve not only economic, but also all political, social, and cultural relations. The social organization of cooperatist communalist farming villages, anarchist communists of the Nōson Seinen Sha claimed, would envision 'for the first time the birth of the possibility of a true anarchist revolution'. ${ }^{30}$

The Nōson Seinen Sha was a group of anarchists that was particularly prominent in promoting and practising cooperatist communalist strategies in imperial Japan. The group consisted of about 23 members, with maybe several hundred supporting farmers in the countryside. Although the group appears to have been rather male-dominated, in terms of class background it was quite diverse. For instance, the group's two most prolific theorists Miyazaki Akira and Suzuki Yasuyuki had very different careers. Miyazaki Akira was born in Igoo in Okayama but grew up in an industrial mining area in Fukuoka prefecture in northern Kyushu. After junior high school, around the time of the Russian Revolution, he started working in the railway industry. He supposedly encountered anarchist ideas during a trip to Hokkaido and through his contacts in a Nihon University student settlement in Tokyo. He read Russian novelists, while pursuing engineering studies at a college in Shanghai. Positioned outside the privileged realms of academia and without a rich family background, working-class Miyazaki was indeed an anarchist from below. His comrade Suzuki Yasuyuki, on the contrary, grew up in typical intellectual circles, as did many contemporary revolutionary theorists and agitators. Suzuki was born in what is today Kitaibaraki, Ibaraki prefecture, in 1903, and went to school in Kamakura, where he

\footnotetext{
${ }^{30}$ Nōson seinen sha, 'Saikin undō no soshiki narabi ni keitai nit suite no ichi teian', in I93o nendai ni okeru nihon anakizumu kakumei undo: Shiryō nōson seinen sha undoshi, (ed.) Nōson seinen sha undoshi kankōkai (Tokyo: Unita shoho, I972 [I931]), p. I3o.
} 
became fascinated with Ōsugi Sakae's interpretations of Christian socialism. In 1925, he entered Waseda University's Department of Law and very soon thereafter started publishing on anarchist thought. Hence, as these short biographical vignettes elucidate, not only did the Nōson Seinen Sha's anarchist ideas not evolve in a singular genealogy, with a fixed set of theoretical ideas, but the group's members also came from varied backgrounds. Very few of them were actual academics who had the privilege of studying at a university, but all of them were intellectually engaged and participated in anarchist study groups, formed independent publishing collectives, or worked for local newspapers. Texts like Miyazaki's I930 'Appeal to the Farmers' (Nōmin ni yobu) attracted academic members, such as Tashiro Gisaburō (I9071967), and convinced them to join the Nōson Seinen Sha's cause. While most members met through anarchist group activities, some of their bonds were also tightened by the shared experience of getting arrested by the police and spending time together in prison.

Together with Yagi Akiko (I895-1983), Hoshino Junji (I9o6-I996), and Mochizuki Jirō (I912-1937), Miyazaki and Suzuki founded the Nōson Seinen Sha in February I93 I and started their own communal experiment in the hinterland of Nagano prefecture. In anticipation of unrest among farmers and an uprising, the group planned to attack the military in Nagano, but this never transpired. A series of robberies in the area, which was meant to undermine the system of capitalist property and to financially support both the commune and the foreseen uprising, only resulted in the imprisonment of some of the group's members in I932. $^{31}$ Due to economic hardship and harsh state repression, by September $193^{2}$ the communal project had already dissolved. Despite its short-lived and small-scale presence, the Nōson Seinen Sha's ideas were nevertheless important as they highlight the significance of anarchist interventions and alternative visions of a better society offered by anarchism. Members of the group did not throw bombs, but they refused to pay taxes and developed a highly sophisticated critique of capitalism as well as of the contemporary socialist movement. In its one year of existence as a practising cooperatist communalist group, the Nōson Seinen Sha struggled against expanding industrialization at a time when major Japanese cities were becoming increasingly turbulent places of 'imperial democracy', with

${ }^{31}$ Crump, Hatta Shūzō, p. I79. 
mass protests, an emerging labour movement, union building, and widespread socialist ideas. ${ }^{32}$ Thus, the Nōson Seinen Sha anarchists also struggled against persistent Marxist dogmatism in the socialist movement, which is particularly visible in Miyazaki Akira's and Suzuki Yasuyuki's writings, and they developed ideals of cooperatist communalism in anarchist communist fashion. The group was not aiming to mobilize the masses (taish $\vec{u})$ as were the socialists. Rather, it had a much more grassroots, democratic, and individualistic sense of the people (minsh $\vec{u}$ ) and of peoples' ability to organize freely in temporary, task-oriented associations of interest groups. In this regard, the group became particularly influential for theorizing and implementing self-sustained communes as well as propagating cooperative ownership, the elimination of hierarchies, and the evolvement of democratic models. ${ }^{33}$ In doing so, the Nōson Seinen Sha was embedded within a broader agrarianist discourse in imperial Japan; yet agrarian anarchism's cooperatist communalist theory and practice, as the following section demonstrates, departed from other agrarianist positions and criticism by fundamentally challenging imperial Japan's feudalist system and agricultural production.

\section{Anarchism and agrarianism in imperial Japan}

During the I930s, agents of the Japanese imperial state aggressively campaigned against any activity that disturbed public peace (chian), especially accusing left-wing activists of espionage and sabotage against Japan's nation- and empire-building. Among the state's prime targets were anarchist groups, some of whom tried to dodge state repression by moving to the countryside to establish cooperatist, self-sustaining communes - 'keeping the state at a distance', to use James Scott's words. ${ }^{34}$ Several waves of repressions against anarchists during the first

\footnotetext{
${ }^{32}$ The term 'imperial democracy' is borrowed from Andrew Gordon, Labor and Imperial Democracy in Prewar Fapan (Berkeley: University of California Press, 1991).

${ }^{33}$ Masayasu Hosaka, Nōson seinen sha jiken: Shōwa anakisuto no mita maboroshi (Tokyo: Chikuma Shobō, 20ıI); Yōko Mihara, 'Nōson Seinen Sha to Gendai', in Nōson Seinen Sha Sono Shiso to Tatakai, (ed.) Hiroshima Museifushugi Kenkyūkai (Hiroshima: Hiroshima Museifushugi Kenkyūkai, I988); and John Crump, The Anarchist Movement in Fapan (London: ACF, I996), respectively, offer very rare contextualization of the Nōson Seinen Sha within the Japanese anarchist movement.

${ }^{34}$ Scott, The Art of Not Being Governed, p. I27.
} 
half of the twentieth century had hit the movement severely. They peaked with the High Treason Incident in I9Io/II, the hunt by the military and police for and assassination of activists and critics following the Great Kantō Earthquake in I923, and the rise of militarism and fascism after the Manchurian Incident in 1931. Moving to the countryside to stay out of the sight and reach of police persecution was but one strategy used by anarchists to survive individually and to maintain the continuity of the anarchist movement. ${ }^{35}$

Yet the anarchists' rural retreat involved more than just hiding in the woods from the agents of the imperial state. Anarchist theory and practice had elaborated on countryside life and agricultural production in various, highly sophisticated ways since the early twentieth century. And for good reason because, despite the increase and expansion of industrialization and urbanization in the early twentieth century, agriculture, which was based on tenant farming labour, remained a vital part of imperial Japan's economy. ${ }^{36}$ A domestic crisis in agriculture, as shown by the I9I8 rice riots, could affect the whole empire, and vice versa. Within Japan, tenant farmers were dependent on highly influential, mostly absent, landowning elites, who often lived in Japan's expanding cities. The imperial state tried to support tenant farmers, but programmes intended to help them to buy land failed due to shortcomings in state funding. And although state officials were eager to maintain small-scale farms because they supposedly personified traditional Japanese virtues, their lack of control on the ground opened a power vacuum that was, once again, filled by landlord elites. ${ }^{37}$ In the I930s, farmers also struggled with falling prices for agricultural products following inflation in the aftermath of the First World War, increasing imports from Japan's colonies Taiwan and Korea, and global market effects in the era of the Great Depression. ${ }^{38}$ Subsequent to the Manchurian Incident and in order to cope with the social crisis of

\footnotetext{
${ }^{35}$ Crump, The Anarchist Movement in Fapan, p. I I. Masako Gavin and Ben Middleton (eds), Japan and the High Treason Incident (New York: Routledge, 2013).

${ }^{36}$ For an overview of Japan's rural history at the end of the nineteenth and in the first half of the twentieth centuries, see Ann Waswo, 'The Transformation of Rural Society, 1900-1950', in The Cambridge History of Fapan, Vol. 6, (ed.) Peter Duus (Cambridge: Cambridge University Press, I988), pp. 541-605.

37 Thomas R. H. Havens, Farm and Nation in Modern Fapan: Agrarian Nationalism, 1870-1940 (Princeton, NJ: Princeton University Press, I974), pp. I5 I-I52.

${ }^{38}$ Penelope Francks, Rural Economic Development in Fapan: From the Nineteenth Century to the Pacific War (New York: Routledge, 2006), pp. 193-218.
} 
impoverished farmers, the Japanese imperial state even initiated mass mobilization campaigns that propagated and supported resettlement of Japanese farmers in the allegedly empty Northeast Asia, which seemed to offer promising opportunities. ${ }^{39}$ That said, anarchist communism, which conceptualized the ideal of self-sustaining, hierarchy-free communes unaffected by domestic power structures as well as global capitalism, thus seems to have directly spoken to the needs of many Japanese people still living and working in the countryside. ${ }^{40}$

In the early twentieth century, with the expansion of capitalism, industrialization, and urbanization, a new discourse evolved from the fantasies of modern life. In imperial Japan, as elsewhere, as Harry Harootunian has persuasively demonstrated, everyday experience became a coeval, key aspect of intellectual engagement with the global historical moment. ${ }^{41}$ The emergence of mass culture, many contemporary critics argued, would erode community, particularly in the countryside - and with it, cultural authenticity allegedly attached to communal village life. Some of Japan's anarchists shared the belief in the eroding forces of capitalism on the village community. Yet, their appeal to rural communal life should not be misconstrued as nostalgia for a harmonious countryside lifestyle. In I9I0, Akaba Hajime (1875-1912), who became famous for his anti-war activism, had already grasped the revolutionary dimension of cooperatist communalism in rural village life, which he outlined in a pamphlet titled 'The Farmers' Gospel' (Nōmin no fukuin), indicating his former affection for Christian socialism. Connecting older forms of Japan's village communities with Peter Kropotkin's idea of mutual aid, Akaba envisioned a 'pure anarchist land' that was not a simple return to an imagined, untouched past, but one that would bring 'advanced scientific knowledge and mutual aid in harmony' to Japan's old village forms. ${ }^{42}$ Anarchists like Akaba, as Sho Konishi has argued, 'gave progressive meaning to the everyday cooperative practices of ordinary farmers. They identified "cooperative

${ }^{39}$ Manchuria also promised to be a place of opportunity for imperial Japan's dissidents. Louise Young, Fapan's Total Empire: Manchuria and the Culture of Wartime Imperialism (Berkeley: University of California Press, 1999).

${ }^{40}$ Elise K. Tipton, Modern Fapan: A Social and Political History (New York: Routledge, 2002), p. III.

${ }^{41}$ Harry D. Harootunian, Overcome by Modernity: History, Culture and Community in Interwar Japan (Princeton: Princeton University Press, 2000).

${ }^{42}$ Hajime Akaba, 'Nōmin no fukuin', Kyōgaku panfuretto, vol. 6, I929 [I9ı̈], pp. I8-I9. This issue, however, was censored and republished in, among others, Meiji Bunka Shiryō Sōsho, Vol. 5 (Tokyo: Kazama, I96o), pp. 287-304. 
living"... as the means to achieve progressive, democratic and less hierarchical society on a global scale. ${ }^{43}$ For these anarchists, the rural village was not a mere retreat or sanctum from the forces of global capitalism, but the very locale of everyday experience and modern life.

Of course, anarchists were among a wider and heterogeneous group that fantasized about agrarian country life. Since the Meiji Restoration in I868, an agrarianist discourse grew up in parallel with Japan's modernization project, which peaked in the pre-war period in the 1930 s. ${ }^{44}$ Dominant agrarianism (nōhonshugi), to quote Thomas Havens, 'included a faith in agricultural economics, an affirmation of rural communalism, and a conviction that farming was indispensable to those qualities that made the nation unique'. ${ }^{45}$ Agrarianist elite conservatives criticized industrialismbut not capitalism itself - as an aberration that weakened agriculture, forcing farmers into the factories and creating a gap between the rich urban centres and poor rural peripheries. They imagined agriculture and rural farming communities as the nation's backbone, feeding its population, supplying healthy citizens for its military, and guaranteeing stability and security in the overall aim of achieving wealth and national strength. Agrarianism became increasingly popular in the first half of the twentieth century and attracted folklorists like Yanagita Kunio (1875I962) to represent the farming village as the last bastion of Japan's timeless cultural essence, in contrast to modern life which was associated with urban centres. ${ }^{46}$ During the agricultural crisis of the late ig2os and early I93os, fascist agrarianists (nōhonshugisha) such as Tachibana Kōzaburō (1893-1974) repopularized the imagined purity of communal, self-sustaining farming life. They rejected existing feudal structures and encouraged cooperative villages as the foundation of a social order that would tie farmers together materially and spiritually. Their ideas entailed a limited critique of capitalism as a destructive force that undermined a harmonious and 'natural' country life. Yet, like its conservative predecessor, fascist agrarianism also clung to private property and favoured patriarchal gender hierarchies in imperial Japan's family system. ${ }^{47}$

${ }^{43}$ Sho Konishi, 'Ordinary Farmers Living Anarchist Time: Arishima Cooperative Farm in Hokkaido, I922-1935', Modern Asian Studies, vol. 47, no. 6, 2013, pp. I845-1887, p. I846.

${ }^{44}$ Tipton, Modern Fapan, p. II5.

${ }^{45}$ Havens, Farm and Nation in Modern Japan, p. 8.

${ }^{46}$ Harootunian, Overcome by Modernity, p. 28.

${ }^{47}$ Stephen Vlastos, 'Agrarianism without Tradition: The Radical Critique of Prewar Japanese Modernity', in Mirror of Modernity: Invented Traditions of Modern Fapan, (ed.) Stephen Vlastos (Berkeley: University of California Press, i996), pp. 83-93. 
Anarchists' promotion of cooperatist communalism was embedded within an established agrarianist discourse from a broad political spectrum in imperial Japan that articulated a critique against modernity. However, anarchist theory and practice departed from conservative, folklorist, and fascist agrarianism in crucial ways. Private property and the division of labour in capitalist modes of production, as well as patriarchy and class divisions, were forms of power that anarchists attempted to destroy and overcome. They also did not intend to invert the hierarchy between cities and villages, as some agrarianists had proposed, but to abandon any sort of hierarchy altogether. ${ }^{48}$ Moreover, anarchists developed revolutionary notions of nature, the environment, and thus, ultimately, human existence that were much more progressive and scientifically based than conservative and fascist conceptions of nature and the countryside. Sho Konishi has demonstrated that Japanese anarchists increasingly turned to science after the Russo-Japanese War (1904/05). Their eclectic reading of Russian and French evolutionary theory, microbiology, and cosmology, all of which dealt with mutual aid among prehistoric humans and animals, symbiotic microbe organisms, and a decentred universe, were key references in their attempt to scientifically prove anarchists' conceptualization of cooperatist communalism without the need for hierarchy and (state) authority in social organization. Based on scientific knowledge, anarchists considered cooperation and mutual aid-as opposed to exploitation and competition-to be the engines of a distinctive, modern temporality in historical progress and civilization. ${ }^{49}$

Agrarian anarchist Ishikawa Sanshirō, for instance, embedded human existence in a constant negotiation with nature. He argued that contemporary capitalist industrial production and urban life would inevitably be intertwined with exploitation, inequality, and unhealthiness, and was therefore unnatural. Instead, his understanding of social organization as 'a vast, horizontal collection of interacting parts with no centre that came together to foster (agricultural) production' led him to plead for a healthy life in accordance with nature. ${ }^{50}$ This constant dynamic would prevent the establishment of hierarchies and allow individuals the freedom to express themselves. Referring to ancient Greek and Edward Carpenter, Ishikawa even

${ }^{48}$ Crump, The Anarchist Movement in Fapan, pp. I21 and 146.

${ }^{49}$ Konishi, Anarchist Modernity, Chapter 6.

${ }^{50}$ Robert Stolz, 'So You've Converged-Now What? The Convergence of Critique', fapanese Studies, vol. 34, no. 3, 2014, pp. 307-323, p. 317. 
redefined democracy, claiming that the original meaning of demos would encompass not only the common people, but also a people attached to the soil or earth $(d o)$. He translated 'democracy' into Japanese as domin kurashi, coining a term that sounds like democracy and simultaneously signifies 'the life of a people attached to the earth'. This attachment, according to Ishikawa, would enable people to realize their individual nature or virtue through hard yet non-exploitive work that ultimately makes freedom possible. ${ }^{51}$

The anarchist communists of the Nōson Seinen Sha shared a belief in the strength of cooperative farming villages to act as a bulwark against the forces of global capitalism, and conceptualized the organization as a powerful revolutionary strategy that was more than just a naive dream of liberty. And they closed the gap between the various forms of libertarianism, agrarianism, and communalism prevalent in I920s imperial Japan. ${ }^{52}$ Despite a nativist, back-to-nature appeal-which on first sight appears as a narrow-minded glorification of a premodern countryside lifestyle - the Nōson Seinen Sha was actually a globally conscious, progressive group. Similarly to its predecessors and contemporary comrades, it participated in the exchange and appropriation of ideas and practices from various strands of radical thought from all around the world. As Sho Konishi has shown in a case study of the Arishima Farm in Hokkaido in the I920s, anarchists in Japan considered their cooperatist communes to be part of a globally synchronic endeavour for the improvement of human life all over the world. ${ }^{53}$ In a similar vein, the Nōson Seinen Sha conceptualized a progressive form of cooperatist being and offered an agrarianist model that was distinct from its conservative, folklorist, and fascist counterparts. It promoted cooperative work without the aim of profit and private property, and engaged in theoretical debates with the currents of anarchist theory and its Western epistemological hegemony. Its vision of an anarchist modernity, as this article will discuss in more detail in the following sections, was for a hierarchy-free social organization without state authority, on autarkic but collaborating farming communes. And they put their vision into practice by building a net of communes in Nagano prefecture in I93I.

\footnotetext{
${ }^{51}$ Konishi, Anarchist Modernity, p. 339.

${ }^{52}$ Hosaka, Nōson seinen sha jiken, p. 86.

${ }^{53}$ Konishi, 'Ordinary Farmers Living Anarchist Time', p. I846.
} 


\section{Anarchist theory and practice: appealing to farmers and decentralizing the anarchist movement}

'The voice of the farming villages' poverty has indeed been around for a long time. Among all people there is no one who has not heard it.' Yet, 'nobody else but the farmers themselves can rescue the farming village' wrote Miyazaki Akira in his introduction to 'Appeal to the Farmers' (Nōmin ni yobu). ${ }^{54}$ Written in 1930 under the pen name Soeta Susumu, it was published in the first issue of the anarchist journal Kurohata (Black Flag). The piece was later republished as a pamphlet and became the theoretical foundation of the Nōson Seinen Sha. It offered a practical revolutionary approach and embedded cooperatist communalism within a profound critique of global capitalism and its regional forms and political systems.

In writings such as 'Appeal to the Farmers', Miyazaki held up the farming village as the key site for social revolution. The three main tasks, he argued, were to live in an autarky, to possess only shared property, and to establish communal welfare based on mutual aid. As the title indicates, the pamphlet was meant to appeal especially to farmers: 'the liberation of the farming village must come at the hands of the farmers', who, Miyazaki claimed, would know their own needs best (jibun jishin). Thus, farmers should not believe in the lie of peasants' lawful liberation from above after the supposed end of the feudal system. Moreover, they should never accept help from the bourgeoisie. The cooperative production and consumption of food and other necessities by farmers would undermine the hegemony of the ruling class (shihai gaiky $\overrightarrow{\text { ) }}$; the creation of self-sustaining communes was therefore fundamental for liberation. Anarchist communism was thus no longer a future goal, as Miyazaki considered that farmers organizing anarchist communes and putting cooperatist communalist visions into practice would cause an instant social revolution.

The first step towards accomplishing cooperatist communalism, according to the Nōson Seinen Sha, was to understand that the communal life in farming villages was the only possible way of life. Famers' products, Miyazaki believed, were supposed to meet the producers' own needs only. This would be a universal law, as entering the capitalist market by exchanging agricultural goods for money would

\footnotetext{
${ }^{54}$ Akira Miyazaki, 'Nōmin ni yobu', in Nōson Seinen Sha Shiryō: Shakai Mondai Shiryō Sōsho I/I2, (ed.) Shakai Mondai Shiryō Kenkyūkai (Kyoto: Yutaka, I972 [I930]), p. 5II.
} 
inevitably ruin village life (seikatsu no reiraku). Thus, Miyazaki asked, 'How can village life stand on its own feet without selling rice, vegetables and subsidiary products, and without any money?' His logical conclusion was that for a village to achieve absolute independence, free of money and market forces, it needed to become self-sufficient (jikyzu jisoku): 'Is facilitating the autarky of the farming village producing food from the soil not the most important issue? ${ }^{55}$ This rhetoric was obviously embedded in inter-war Japan's agrarian discourse. Miyazaki's strong emphasis on rice as the pivotal agricultural product perpetuated a culturalist sentiment for Japanese nationalist exceptionalism, and its metaphorical use seems to be similar to imperial Japan's nationalist agrarianism. ${ }^{56}$ Yet, it is remarkable how Miyazaki departed from nationalist and spiritualist readings of the countryside and agricultural production in his emphasis on the universal materiality of the human body at the heart of agricultural labour. Of course, there is an amount of vague spirituality in Miyazaki's assertion that eating something different from what you produce by yourself makes life incomplete (fukanzen), leaving the exact meaning of incompleteness up to the reader's imagination. Unlike other agrarianists, however, Miyazaki was not arguing for a spiritual basis to products such as rice to connect humans, soil, and their ancestors. The production of food - rice in this caseinstead signifies an existential human need that must be satisfied. The soil or earth nevertheless played a pivotal role in this task, which becomes particularly visible in the trope of the 'farming village producing food from the earth' (tabemono wo do kara tsukuri nōson). According to Miyazaki, the connection between earth and humans was purely materialistic, and its harmony manifested in the reciprocity of human labour cultivating the earth, which in turn provides crops and harvest for human existence. This universal materialistic law of a reciprocal, harmonious relationship between nature and humans, maintained through earth's matter and energy as well as human agency, would be the foundation for social mechanisms. In line with the argument formulated by the English anarchist George Barrett, the production of and access to food- 'the individual struggle to live, in its most simple and elementary form'results in society and lies at the heart of social organization. ${ }^{57}$

\footnotetext{
${ }^{55}$ Ibid., p. 527.

${ }^{56}$ For an analysis of rice in modern Japanese history, refer to Emiko Ohnuki-Tierney, Rice as Self: Fapanese Identities through Time (Princeton: Princeton University Press, I993).

${ }^{57}$ George Barrett, Anarchist Revolution (London: Freedom Press, 1920, 2nd edn [I9I2]), p. I3.
} 
Self-sufficient manual farming labour, Miyazaki was convinced, would take control of fundamental social mechanisms. It would overcome capitalist modes of production, ownership, and authority, which ultimately would allow free individuals to associate and was thus the most promising strategy to achieving liberation. ${ }^{58}$

Organizing villages along self-sufficient lines of production indeed had revolutionary potential. The emphasis on self-sufficiency through mutual aid was supposed to undermine state authority, the capitalist division of labour, and the exploitation of people and nature. Similarly to Akaba Hajime, Miyazaki also imagined that imperial Japan's cooperatist communities would be built on land 'that farmers are supposed to use freely', and that mutual aid would be combined with advanced technologies to achieve self-sufficiency as opposed to profit. ${ }^{59}$ A key concern was money, which enabled exploitation through profit and division of labour, and was therefore considered a force that eroded solidarity. Miyazaki wrote, 'With the birth of money in society happiness vanishes', arguing that money divides people, humans and their products, farmers and workers, cities and countryside. Self-sufficient farming within the village community and shared property would curb the threat of money and prevent the establishment of hierarchies. ${ }^{60}$

When it comes to the issue of tax payments $(n \bar{o} z e \ell)$, in particular, anarchists' vision of self-sufficient villages and rejection of money directly attacked the state's authority. As Miyazaki explained, modern state institutions' demand for tax payments from farmers was only possible through the production of revenue gained by selling agricultural products to the market in exchange for money. Tax revenues, in turn, are crucial to the survival of state authorities, as they pay for the state's administration, police, and military. Therefore, Miyazaki polemicized, the paying of tax 'covers the pension of the government's bureaucrats, soldiers and police officers who have looked down on the people with arrogance'. Moreover, tax payments would only help capitalists to make profit. As they support state institutions and authority, and sustain capitalist modes of production, they therefore entail exploitation. Instead, the people could provide all the alleged benefits of tax payments themselves. Following on from his initial remarks, Miyazaki argued that all matters of village life, such as

\footnotetext{
${ }^{58}$ Miyazaki, 'Nōmin ni yobu', p. 518.

${ }^{59}$ Ibid., p. $5^{26}$.

${ }^{60}$ Ibid., p. $5^{23}$.
} 
'putting up bridges, building roads, setting up irrigation for uncultivated land, building storehouses and communal manufactories', could be solved by village people themselves: 'When everything is done by the village cooperation, there is no basis for government's theft of tax money. ${ }^{61}$ Whereas other agrarianists had argued for self-sufficiency and a reduction in taxes so as not to support a corrupt government and what they called a 'diseased', 'unnatural', and allegedly 'un-Japanese' urban industry with its ruling elites, the cooperatist communalist anarchists of the Nōson Seinen Sha developed a much stronger anti-state and anti-nationalist strategy. Refusing to pay tax was a radical rejection of the imperial state and its projects, and a clear statement against the landowning and capitalist elites.

Money and tax payments were also directly linked to issues of security and war. Japan's elites, according to Miyazaki, wanted people to believe that all citizens' support for the state, economy, and military in a collaborating society (kyōdo shakar) generated national unity and strength, to everyone's benefit. On the contrary, Miyazaki argued, the government's call for unity and security, a call amplified by the demands of 'bureaucrats, police officers and bourgeois educators' to honour the nation, would only be a distraction. The nation, national unity, strength, and security in a collaborating society of and for all people were mere constructions of the ruling class. The imperial state, its agents, and the bourgeoisie would be the only ones profiting from the people's labour and tax payments. Moreover, Miyazaki considered money, taxes, and capitalism to be the foundation for war preparation as modern industrial production was indispensable for modern war and, arguably, vice versa. And the defence of the collaborating society (kyōdo shakai no bōkyo) that the aura of war, as well as warfare itself, was necessary to secure the nation's wealth and strength against foreign threats for the benefit for all citizens would, in fact, only serve the ruling class. ${ }^{62}$

Miyazaki's line of argument was obviously a direct critique of imperial Japan's nationalism, industrial expansion, and rising militarism in the inter-war period. The anarchists' intervention was indeed much more radical than other groups' agrarianist promotion of self-sufficient countryside life organized in farming villages. Self-organizing farmers without internal or external authority who rejected paying taxes clearly

\footnotetext{
${ }^{61}$ Ibid., p. 525 .

${ }^{62}$ Ibid., pp. $5^{27}-528$.
} 
undermined capitalist modes of production and imperial Japan's modernization project which was heavily focused on industrialization and urbanization. Yet the Nōson Seinen Sha envisioned that farmers could, and should, liberate themselves. Ironically, however, the voices of the farmers themselves can hardly be heard in Miyazaki's writings. The essay's title - 'Appeal to Farmers'-already indicates that Miyazaki ultimately spoke to the farmers and in favour of them, and not with them-and definitely never let the farmers speak for themselves. Indeed, his appeal might have attracted other anarchist intellectuals rather than the subaltern tenant farmers in the countryside. Gayatri Spivak, among others, has called attention to the inherent epistemic violence in the desire of intellectuals to represent subaltern people of colour. ${ }^{63}$ Miyazaki, too, repeated the mechanism of epistemic violence to a certain extent: he fell into the trap of sympathizing with the oppressed - the speaking for the farmers and their interests - thereby reproducing a hierarchy between the theorizing and agitating intellectual and the farmer as supposed revolutionary subject. Nonetheless, Miyazaki's rhetoric strategy was not to position himself as the spokesperson for the farmers but to argue that only farmers themselves, through farm life itself, could achieve full liberation. Indeed, it underscores an insistence on agency and self-sustaining practice - the organization of cooperatist communalist farming villages - as opposed to theorizing revolutionary action. The Nōson Seinen Sha's revolutionary conception of cooperatist communalism thus corresponds directly to what Murray Bookchin argued several decades later: '[O]ur decision to create a better society, and our choice of the way to do it, must come from within ourselves, without the aid of a deity, still less a mystical "force of nature" or a charismatic leader. ${ }^{, 64}$

The notion of leaderless and allegedly untainted or pure anarchism in farming village communes continued to characterize the Nōson Seinen Sha's theory and practice. In a less dramatic manner, one might comprehend the anarchists' understanding of purity as a matter of consequence. Their idea of organized farming villages as the basis for social revolution aimed at avoiding the creation of any avenues for the (re-)emergence of hierarchies after liberation has been achieved. In a

\footnotetext{
${ }^{63}$ Gayatri Chakravorty Spivak, 'Can the Subaltern Speak?', in Marxism and the Interpretation of Culture, (eds) Cary Nelson and Lawrence Grossberg (Urbana and Chicago: University of Illinois Press, I988), pp. 27I-313.

${ }^{64}$ Bookchin, Social Ecology and Communalism, p. 79.
} 
pamphlet titled 'The Organisation of the Recent Movement and a Proposal on the Form it should Take', published collectively in I93I under the pseudonym 'Association for Bread and Liberty' (Pan to Fiyusha), the Nōson Seinen Sha emphasized this point. The group promoted a clear break with syndicalism and promised to continue to sharply criticize any other 'impurities' (fujunbutsu) in the anarchist and socialist movement. In order to convince readers that they were 'on the straight way to anarchist revolution', the Nōson Seinen Sha argued that it would be imperative to clarify the form and organization the anarchist movement should take. ${ }^{65}$

Unsurprisingly, the Nōson Seinen Sha envisioned a movement free of any form of centralized organization and emphasized autonomous action and decentralization as the only meaningful tactics. According to its critique, it had been an error of the previous mass-oriented anarchist and labour movement to establish permanent groups for education, labour, propaganda, and so on. Their criticism targeted, in particular, nationwide anarchist organizations such as the Kokushoku Seinen Reimen (shortened to Kokuren), which had emerged from December I925 out of various militant groups and identified itself as an avant-garde minority struggling for class liberation. ${ }^{66}$ Taking the example of the propaganda leaflets of anarchist groups that operated nationwide, the Nōson Seinen Sha complained about the almost endless meetings and arduous decision-making processes that were necessary to determine who would eventually write, proofread, print, and distribute a statement or leaflet. Such long processes were ineffective and, moreover, made the movement vulnerable, because reliance on an unchanging organizational structure made it easier for the authorities to persecute and eventually paralyse the movement. ${ }^{67}$

In contrast, the Nōson Seinen Sha envisioned only occasional, task-oriented groups. One of its catchphrases was 'gather when necessary, dissolve when finished'. This became a motto to articulate the temporary nature of the grouping together of individuals who shared interests to achieve a particular goal. In vainglorious terms, the Nōson Seinen Sha even claimed that, 'This is where for the first time

\footnotetext{
${ }^{65}$ Nōson Seinen Sha, 'Saikin undō no soshiki narabi ni keitai nit suite no ichi teian', p. I25.

${ }^{66}$ Crump, The Anarchist Movement in Japan, pp. 69-71.

${ }^{67}$ Nōson Seinen Sha, 'Saikin undō no soshiki narabi ni keitai nit suite no ichi teian', p. I25.
} 
the possibility of a true anarchist revolution is born. ${ }^{68}$ The strategy of organizing the masses to rise up to achieve an anarchist revolution, either through intensive propaganda or planned and/or spontaneous uprisings, would have been unsuccessful under the prevailing circumstances. Such actions would even cause harm to the movement, because it would have made it easy for state authorities to intervene, win the struggle due to the imperial state's superior force, and reaffirm its authority. Even more importantly, the development of individual freedom was at stake. Instead of a centralized mass organization, the meeting up of individuals would allow them to articulate their personal needs and desires independently. Ultimately, the Nōson Seinen Sha argued, such individual-based contact and association around a single issue and repeatedly confronting the individual with a 'new worldview' (atarashii sekaikan) would create a dynamic from which a 'new human' (shinjin) - an anarchist - would emerge who bore the potential for full liberation. Its call to immediate action was: 'Refuse bottom-up as well as from periphery to the centre! From formation to decentralisation! Autonomous, decentralised action rather than centralisation! ${ }^{69}$

The Nōson Seinen Sha's strong rhetoric criticizing the contemporary anarchist movement and theorizing the necessary steps for a successful anarchist revolution was not free of contradictions. As John Crump has stressed, contemporary anarchists, including Hatta Shuzō (I886-I934), pointed out that regarding organization there would be some inconsistencies between the group's theory and practice. Despite the call for equality between anarchists and common farmers, those Nōson Seinen Sha members still living in urban centres believed in the group's avant-garde, revolutionary force. Hatta heavily criticized the Nōson Seinen Sha for pretending to claim to have no leadership while simultaneously setting themselves up as providing guidance to the masses. ${ }^{70}$ Despite the validity of such criticism, the Nōson Seinen Sha's anarchist theory of action was nevertheless remarkable. It might appear as just a simple, nativist, retrogressive dream of retreating from industrial urbanization to a seemingly untainted natural environment. Yet the group's degree of awareness of the forces of capitalism and its strategies to undermine them are distinctive and highly progressive. In particular, the emphasis on a self-sufficient farming life in which free

\footnotetext{
${ }^{68}$ Ibid., p. 128.

${ }^{69}$ Ibid., pp. I28 and I30.

${ }^{70}$ Crump, Hatta Shūzō, p. I77.
} 
individuals were connected by mutual aid and were organized temporarily in task-oriented associations becomes even more effective by connecting such a life with a refusal to pay taxes in order to shatter the existential basis of the imperial state. Moreover, Nōson Seinen Sha's anarchism was embedded into a perspicacious framework promoting a 'new worldview', indicating the group's globally conscious vision for liberation. Such global appeal becomes particularly apparent through its emphasis on creating the 'new human', which discursively connected Japanese anarchists to the endeavour of social movements worldwide. Similar poetics of the 'new human' synchronously emerged in movements and places as different as Weimar Republican Lebensreform, Soviet physical culture, and Mohandas Gandhi's bodily exercises. ${ }^{71}$ Hence, as the following section will demonstrate, Japanese anarchists from the Nōson Seinen Sha were exceedingly modern in and through their globally conscious trans-imperial anarchism.

\section{Anarchism across empires: the Nōson Seinen Sha's critique and appropriations}

Trans-imperial connections-physical manoeuvring and intellectual journeying within and beyond imperial boundaries - were characteristic of Japanese anarchists. The contact, collision, and conjunction of revolutionary theory and practice worldwide was pivotal for developing its ideas and sharpening its arguments. In particular, appreciation of and equally important-demarcation from socialist thought and revolutionary experience the world over was crucial to the Nōson Seinen Sha's identity politics in terms of establishing its distinct yet universalist cooperatist communalism. There is not one singular source or movement that can be determined as the origin of its anarchism. Rather, a multiplicity of influences shaped the group's anarchist theory and practice.

The Russian Revolution and subsequent Bolshevik rule became a major point of reference for revolutionary thought worldwide-it allowed

\footnotetext{
${ }^{71}$ For comparative purposes, see, among others, Bernd Wedemeyer-Kolwe, 'Der neue Mensch': Körperkultur im Kaiserreich und in der Weimarer Republik (Würzburg: Königshausen and Neumann, 2004); Susan Grant, Physical Culture and Sport in Soviet Society: Propaganda, Acculturation, and Transformation in the Ig20s and I930s (New York: Routledge, 2013); Joseph S. Alter, 'Gandhi's Body, Gandhi's Truth: Nonviolence and the Biomoral Imperative of Public Health', Journal of Asian Studies, vol. 55, no. 2, I996, pp. 30I-322.
} 
'utopian daydreaming', to quote Neil McInnes's disparaging remark, and had a decisive but also divisive impact on socialist/communist movements. ${ }^{72}$ Japanese anarchists were well aware of Bolshevism's revolutionary force in transforming society and acknowledged its vision of necessary fundamental social change. They even agreed with the idea of 'creative violence' (sōzōteki bōryoku) as a destructive force that would shatter the existing social, economic, political, and cultural order and would be imperative to achieving full liberation in a newly built social organization. Yet members of the Nōson Seinen Sha, like many other leftist revolutionary theorists and activists in Japan and elsewhere ${ }^{73}$ had reservations about Bolshevism's methods and heavily objected to it for various reasons. The group criticized centralized party building as well as the submission of the individual to the will of the party, labelling it as an avant-garde revolutionary force and constraint collectivization. In bold language, Miyazaki called attention to the Bolsheviks' foreseeable oppression: 'To achieve their high ambitions they will exploit the people.' In order to illustrate Bolsheviks' true and bad intentions, Miyazaki compared its intervention with sixteenth- and seventeenth-century Japanese feudalist regimes under Toyotomi Hideyoshi and Tokugawa rule. Feudal lords would also have claimed to aim for the 'transformation of society' (shakai no henkaku); however, 'from the position of the people [minshü], common people's life was still not liberated'. Miyazaki agreed with the Bolsheviks that with 'today's landowning capitalists' government ... there is [a] need to take the political power of the established ruling class in the people's own hands by force'. Yet, he asserted that 'the people betrayed by the government ... are certainly as easily betrayed by the Bolsheviks'. Miyazaki was convinced that the Bolsheviks misunderstood the fundamental principles of successful revolutionary transformation and that this was thus a sign of Bolshevism's anti-revolutionary, backward, even reactionary methods. This would be particularly visible from the perspective of the farming village. 'By the time when the Bolsheviks have seized power in a red government (sekishoku seifu) based in the city, the Bolshevik functionary comes to the village with commands for the peasants, the first one being "requisition of harvest". Without any reason they go and rob the

${ }^{72}$ Neil McInnes, 'The Labour Movement: Socialists, Communists, Trade Unions', in The Impact of the Russian Revolution, I9I7-I967, (ed.) Royal Institute of International Affairs (Oxford: Oxford University Press, 1967), p. 37.

${ }^{73}$ Bertrand Russell, Bolshevism: Practice and Theory (New York: Harcourt, Brace and Howe, i920). 
peasants' products. ${ }^{74}$ Any resistance to such orders would be severely punished, and Miyazaki underscored this by reminding his readers of the Great Kantō Earthquake in 1923 as well as the March I5 Incident from I928, and how dissidents were persecuted, arrested, and assassinated by government officials in the wake of these events. Thus, Miyazaki urged 'the dear farmers' to understand that socialist transformation and five-years plans were no less than 'dirty deception' (fuketsuna giman) that would not lead to their liberation. ${ }^{75}$

Nōson Seinen Sha's radical critique not only targeted Bolshevism, it also attacked anarchist and socialist movements and their advocates worldwide. In his History of the Japanese Anarchist Movement from I932, Suzuki Yasuyuki discussed at length the weaknesses and pitfalls of previous socialist theory and practice, including the European tradition of anarchism. In particular, he heavily criticized Mikhail Bakunin and his plea for a 'bottom-up' (shita kara ue e) approach as 'destructive destruction' (hakai tekina hakai). On the contrary, Suzuki put the case for the Nōson Seinen Sha's 'practical anarchism' (jissen tekina museifushugi) and its 'constructive destruction' (kensetsu tekina hakai). He also emphasized that the group's most important shift in terms of anarchist theory and practice would not offer liberation to the farmers (nōson no naka e), but instead a non-hierarchical, decentralized, temporal, and task-oriented organization from within their midst (nōson no naka kara). This could be accomplished through the immediate implementation of an egalitarian system of production and consumption organized in cooperative farming villages. ${ }^{76}$

By discussing and criticizing the goals and failures of socialist and anarchist movements in Russia, France, Germany, and Spain, Suzuki integrated Japanese anarchism into a worldwide struggle for liberation. He could not base his arguments on Nōson Seinen Sha's achievements or popularity among the masses. Rather, in contrast to what he called the 'emotional', and therefore foredoomed, efforts in the West, Suzuki underscored the group's rationality. He insisted that it would be an enlightened (keimō tekina), science-based movement, and that its theory and practice would ultimately lead to revolution. ${ }^{77}$ Suzuki's reasoning was grounded in a fundamental understanding of social organization as

\footnotetext{
${ }^{74}$ Miyazaki, 'Nōmin ni yobu', pp. 532-533.

${ }^{75}$ Ibid., p. 535 .

${ }^{76}$ Yasuyuki Suzuki, Nïhon museifushugi undōshi (Tokyo: Kokushoku sensensha, I99o [1932]), pp. 56-57.

${ }^{77}$ Ibid., p. 59.
} 
social organism. This global idea was widespread and appeared alongside competing and conflicting political positions and scientific approaches. Anarchists like George Barrett, whose Anarchist Revolution Suzuki had translated in 1930, as well as, among many others, socialist and social hygienist Auguste Forel in Switzerland, sociologist Émile Durkheim in France, evolutionist Herbert Spencer in England, and the Nazi vision of the Volkskörper fostered an understanding of society as a complex social organism that forms a whole through the functionality of all its social parts and being. ${ }^{78}$ Such a shared understanding underscores the Nōson Seinen Sha's progressive position globally. Yet Suzuki and Miyazaki did not dwell only on the group's rationality and modernity woven into its narrative of anarchist theory and practice, they departed from other notions of social organism in crucial ways. They emphasized that human agency was not limited to its functionality for the whole social body, but was an individual freedom to choose and experience labour and association in a liberated society, based on the idea of mutual aid.

Suzuki did not dismiss all Western science. On the contrary, he provided an anarchist reading of history, anthropology, and evolutionary theory with reference to Peter Kropotkin as well as Élisée Reclus, an anarchist geographer whose thought had a strong impact on the development of eco-anarchism. He demonstrated the pivotal and universal significance of mutuality for social organization and human existence. Suzuki thought of contemporary capitalist society as being 'in the middle of serious unrest' and claimed that people blinded by Darwinist evolutionary theory, and who embraced life as a form of competition, would intensify the world's crisis. He rejected Marxism, because it would not offer any solution due to its narrow focus on the connections between human beings determined by capitalism and the struggle for the means of production. More important, according to Suzuki, was the emphasis on mutuality or mutual aid - not competition or struggle - as a historical force for liberation. Studies on the life of monkeys and prehistoric human activity had proven, he argued, that

${ }^{78}$ Barrett, Anarchist Revolution, p. I8; Jessica R. Pliley, Robert Kramm and Harald Fischer-Tiné (eds), Global Anti-Vice Activism: Fighting Drinks, Drugs and 'Immorality' (Cambridge and New York: Cambridge University Press, 2016), p. I4; Émile Durkheim, The Division of Labour in Society (London: Macmillan, I984 [I893]), p. II; Boaz Neumann, 'The Phenomenology of the German People's Body (Volkskörper) and the Extermination of the Jewish Body', New German Critique, vol. 36, no. I (Io6), 2009, pp. I49-18I. 
conflict and struggle in society had emerged alongside the development of inequality and hierarchy caused by the organization of clans and classes. Following Élisée Reclus, Suzuki thus promoted another take on world history in terms of universal harmony and social equality:

It is deeply moving to carefully observe the entire landscape of the earth, its nature of infinite variety and the effect of human activities' eternal force causing its harmony [...]. Yet, the very same earth-sustaining and furthermore providing for humankind - and heaven - illuminating the world and supplying the universe's energy - together with a matrix of human beings in harmoniously vibrating conditions can be seen and sensed. ${ }^{79}$

Dismissing Suzuki's claims as mere naive, idealist belief in a better world that had supposedly existed in ancient times and which might be envisioned in the far future does not do justice to his grounding in scientific reasoning. Suzuki's line of argument was very close to the observations that Japanese anarchists had articulated a decade before. For instance, in the I920s Ishikawa Sanshirō had called for a similar cosmological approach, labelled 'unity in multiplicity', arguing, in Sho Konishi's words, for 'the infinity that characterised the centreless universe', which dictates 'the absence of an absolute subject of power and the limitlessness of possibilities for human interaction and cultural invention'. ${ }^{80}$ Humankind would need to overcome hierarchy and competition, Suzuki insisted, so as to progress towards harmonious and free social organization. Suzuki and the Nōson Seinen Sha were convinced that cooperatist communalism, existing in anarchist communes that facilitated mutual aid, would be a necessary first step towards achieving a constant cosmological dynamic that would prevent the establishment of hierarchies and competition.

Despite Suzuki Yasuyuki's critique of Western socialist and anarchist theory and practice, his narrative strategy of citing Western references appeared to him to be the only way to gain legitimacy. Despite his strong efforts to distance himself, his writings reveal an underlying continuity with a Western epistemological matrix, in which European thought appears as the only point of reference to give authority to any kind of progressive, rational thinking. Suzuki's critique thus seems to have been trapped in the dilemma articulated by Dipesh Chakrabarty, who has argued that while the terms and concepts from the European tradition are inadequate, they are nevertheless indispensable for

\footnotetext{
${ }^{79}$ Suzuki, Nïhon museifushugi undōshi, pp. 8I-82.

${ }^{80}$ Konishi, Anarchist Modernity, p. 340.
} 
evaluating non-Western phenomena in order to them to be recognized. ${ }^{81}$ It is remarkable that Suzuki pointed out basic misunderstandings of social mechanisms and revolutionary practice inherent in movements such as Bolshevism. In doing so, he underscored the emotional character of Western socialist and anarchist movements, and disparaged its revolutionary romanticisms as the main reason for the failure of social revolutions. In contrast, Suzuki emphasized the Nōson Seinen Sha's rationality and progressiveness. It is his insistence on universality and scientifically certified forces of human existence, agency, and creativity - such as mutual aid in evolutionary theory - that undermined the West's claim for rationality. Yet his reproduction of Western epistemic hegemony gave authority to Suzuki's logic, rendering cooperatist communalism as a globally conscious and modern approach to social innovation and, ultimately, liberation.

An attempt to decentre social revolution from following a Eurocentric script is also apparent in the Nōson Seinen Sha's engagement with non-Western revolutionary theory and practice. Contemporary Asian movements sparked interest for obvious reasons, one being their spatial proximity to the orbit of the Japanese empire. Nevertheless, Japanese anarchists could have just ignored other Asian movements and only looked at the struggles of European, American, and Russian comrades. Miyazaki, on the contrary, compared the Nōson Seinen Sha's concepts with, for example, those of the anti-colonial struggle in India. In particular, Gandhi's campaign of non-cooperation, translated by Miyazaki as muteikō shugi and which he even referred to as 'Gandhism' (ganjizumu), was of interest to Japanese anarchists. The non-cooperation campaign was part of Gandhi's larger concept of non-violent resistance (satyagraha) in the Indian independence movement. Miyazaki argued that non-cooperation as conceptualized by Gandhi would have both an economic and a political dimension. The boycott of British goods and the sole consumption of Indian products instead would indeed undermine the colonial administration and help stop the generation of revenue for the British government. He particularly praised Gandhi's understanding of autarky to gain independence. Yet, Miyazaki believed that 'Gandhism is incomplete' because its focus on changing the economy and the political system would not change the social organization in which they were rooted. India's independence from

${ }^{81}$ Dipesh Chakrabarty, Provincializing Europe: Postcolonial Thought and Historical Difference (Princeton: Princeton University Press, 200o), p. I6. 
British colonial rule might result in a new economy and reformed political system, but without radical change, Miyazaki argued, the bourgeoisie would continue to dominate a hierarchical society that would not liberate the people. $^{82}$

The Nōson Seinen Sha also discussed other revolutionary peasant uprisings in Asia. It addressed incidents and movements in Northeast Asia and British Burma, and evaluated their sustainability and radicalism. However, it did not judge radicalism by the degree of violence in the uprisings, which the Nōson Seinen Sha did not reject per se. For example, it did not condemn the Wanpaoshan Incident of I July I93 I (which involved a clash between Korean and Chinese farmers and resulted in outbursts of anti-Chinese violence all over colonial Korea) for its obvious racism and unnecessary ruthlessness. Rather, it argued that the uprising failed because it could not be turned into a 'revolutionary rebellion' (kakumeitekina bōdo). By contrast, the group praised a series of peasant uprisings in British Burma that later became known as the Saya San Rebellion (1930-1932). Most historiography has highlighted the Burmese peasants' backwardness, prematurity, and lack of organization in similar insurrections, reflecting Marx's distrust of the peasantry, who were regarded as reactionary, showing no solidarity with workers, and having no class consciousness. Many local contemporary socialists and communists in East and Southeast Asia also expressed anti-peasantry feeling, stereotyping farmers as superstitious, too respectful of hierarchy, tradition-bound and therefore fearful of (revolutionary) change. ${ }^{83}$ The Nōson Seinen Sha, however, celebrated Burmese peasants' traits and characteristics:

The recent peasant rebellion spreading in British Burma possesses no centred organisational body [chüshin tekina soshikitai] of any kind. This is peasants' fashion whose autonomous action has no concentrated structure. [...] If the Burma peasants had clung to centralised organisation [shüchu soshiki] and if there had been no autonomy pervaded spirit, the peasants would have instantly been repressed. ${ }^{84}$

In contrast to Marxist doctrine, that of the Nōson Seinen Sha defended the peasantry for their revolutionary practice and, moreover, even

${ }^{82}$ Miyazaki, 'Nōmin ni yobu', pp. 516-517.

${ }^{83}$ Clive Christie, Ideology and Revolution in Southeast Asia, I9oo-I98o (Richmond: Curzon, 200I), pp. $4^{\mathrm{O}-43}$.

${ }^{84}$ Nōson Seinen Sha, 'Saikin undō no soshiki narabi ni keitai nit suite no ichi teian', pp. $\mathrm{I} 25^{-\mathrm{I} 26 .}$ 
underscored their radicalism as revolutionary subjects. Peasant rebellions, it argued, are autonomous, and farmers' self-organization and self-sufficiency made them independent from established imperial bourgeois society and economy. These circumstances would foster the potential to change the system at its roots.

At first glance, it is striking that all of the Nōson Seinen Sha's commentaries never raised the issue of race. The absence of any mention of race and racism in its analysis of events in colonial constellations such as the Gandhi-lead independence movement in colonial India and the peasant rebellion in British Burma is particularly conspicuous. It is especially noteworthy because the British empire's colonial administrations are especially known for their race-conscious 'rule of colonial difference, ${ }^{85}$ Racial taxonomies, hierarchies, and tensions were also significant in Japan's empire-building, as the Wanpaoshan Incident and its aftermath demonstrate. ${ }^{86}$ Being positioned outside the racial and epistemological privileged West, Japanese anarchists could have supported their aim for liberation with anti-racist arguments. Of course, members of the Nōson Seinen Sha might just have been too ignorant or preoccupied to acknowledge racialized hierarchy and power. Its idea of liberation seems to have been too practical, yet also too universalist and abstract, so that perhaps it just could not see any need to recognize the issue. In particular, its idea of the 'new human' was a distraction from the fact that skin colour as a signifier of power matters. As the Nōson Seinen Sha unambiguously argued: 'Our understanding is to breathe a new Weltanschauung [sekaikan] into the new human as quickly as possible. The new human as anarchist will initiate independent autonomous action by determining his own needs and demands $(y \bar{u} k y \bar{u}){ }^{.87}$ Following the logic of Japanese anarchists, its ultimate goal of liberation and equality appears to have allowed no petty differentiation; hierarchies of race, it apparently believed, would dissolve after the new human understood and brought about humanity's true and pure nature of autonomy and liberty.

${ }^{85}$ Partha Chatterjee, The Nation and its Fragments: Colonial and Postcolonial Histories (Princeton: Princeton University Press, I993), p. Io.

${ }^{86}$ On race and racism in the Japanese empire, see Heé, Imperiales Wissen und koloniale Gewalt; Takashi Fujitani, Race for Empire: Koreans as Fapanese and Fapanese as Americans during World War II (Berkeley: University of California Press, 201 I).

${ }^{87}$ Nōson Seinen Sha, 'Saikin undō no soshiki narabi ni keitai nit suite no ichi teian', p. I28. 


\section{Conclusion}

Newspapers and the police alike imagined the Nōson Seinen Sha to be a force that undermined the empire and state authority. The mass media, however, mainly paid attention to the group in 1937, after the police had arrested some of its members between 1934 and 1936, long after its commune project had ended. Some of the arrests occurred in the wake of preparations for a military manoeuvre in Nagano's neighbouring prefecture of Gunma, which emperor Hirohito was meant to attend, and were therefore part of clearing the area of potential threats by the police. ${ }^{88}$ Even in retrospect, they presented the group's network as a kraken whose tentacles had apparently reached into every part of the Japanese empire, from Karafuto to Korea, Taiwan and Shanghai, and of course inside mainland Japan. ${ }^{89}$ Just one day later, Korean newspapers also reported the arrest of members of the group, showing that the news had spread throughout the Japanese empire. ${ }^{90}$ In their reports the police classified the Nōson Seinen Sha as a secret society (himitsu kessha) and stressed that its alleged hidden activities were undermining the imperial state. They even called attention to what they called 'Nôson Seinen Sha-izumu', a phrase in which -izumu (-ism) completely overrated the group's potential threat. The police's labelling gave the group a sneaky, dangerous, and foreign appeal, compounded by borrowing an ending from a foreign language instead of the Japanese character compound shugi. Moreover, the police emphasized the Nōson Seinen Sha's adaption of foreign anarchist thought, mainly from Russian thinkers. ${ }^{91}$ As Umemori Naoyuki has stressed in the context of the persecution of anarchists in the High Treason Incident in I9IO, such a discursive construction of a supposed anarchist threat as coming from outside the Japanese community echoed the imperial state's symbolic crackdown of its internal enemies. The state's intervention in highlighting anarchists' supposed foreignness distinguished between included and excluded imperial subjects, and was subsequently aimed at fostering imperial Japan's community. ${ }^{92}$

${ }^{88}$ Crump, Hatta Shūzō, p. I79.

89 'Nōson seinen sha no kessei', Shinano Mainichi Shinbun, I I January 1937.

90 'Kokushoku kyosanto', Maeil Shinbo, I2 January i937.

${ }^{91}$ Naganoken keisatsubu, 'Himitsu kessha nōson seinen sha jiken ni kansuru kōseki gaiyō', in Tokkō keisatsu kankei shiryō shūsei, Vol. 20, (ed.) Ogino Fujio (Tokyo: Fujishuppan, I993 [1937]), p. 268.

${ }^{92}$ Naoyuki Umemori, 'The Historical Contexts of the High Treason Incident: Governmentality and Colonialism', in Japan and the High Treason Incident, (eds) Gavin and Middleton, p. 63 . 
The emphasis on foreignness in the media and the authorities' representation of the Nōson Seinen Sha, however, also demonstrates the connectedness of its anarchist theory and practice beyond imperial Japan and accentuates its trans-imperial anarchism. Indeed, the Nōson Seinen Sha and other movements' propagation and building of radical utopian communities should be understood as part of a global, synchronic phenomenon. As has been demonstrated, Suzuki's reference to Western anarchist thought and practice is proof of a trans-imperial flow of knowledge, and his globally conscious critique at least indicates that non-Western anarchists were not passive recipients of such knowledge, but actively contributed to its appropriation. As Alf Lüdtke has argued, appropriation - in accordance with the German term Aneignung - always entails rupture, change, and challenge, and therefore does not mean unilateral dissemination. ${ }^{93}$ Moreover, a decentralized, and especially a non-Eurocentric, acknowledgement of non-Western revolutionary theory and practice allows the recognition of historical variety beyond Western master narratives of political struggle. For instance, Japan itself is still not known for a history of dissent, despite the existence of many radical activists and groups. Looking at the Nōson Seinen Sha's writings which address liberation struggles in various places and which are usually ignored in contemporary European thought and activism, opens further perspectives on anarchism and other forms of radicalism in numerous parts in the world. Of course, Russia is most important, given the high impact of Russian anarchist thought on Japanese intellectuals in the first half of the twentieth century. But Nōson Seinen Sha's analysis of Gandhism in India and revolutionary peasant movements in colonial Burma also underscores global entanglements, at least in the awareness of anarchist activists.

A close reading of imperial Japan's anarchists' text and paying attention to their cooperatist communalism offer insights that allow scholarly and political intervention, as does highlighting such silenced histories, with the aim of integrating them into broader conversation-hopefully on historical actors' own terms. The key characteristics of imperial Japan's anarchism, it appears, were its pragmatism, practicality, and universality -building anarchist self-sufficient farming communes that would

${ }^{93}$ Alf Lüdtke, 'Was ist und wer treibt Alltagsgeschichte?', in Alltagsgeschichte: Zur Rekonstruktion historischer Erfahrungen und Lebenswelten, (ed.) Alf Lüdtke (Frankfurt/M. and New York: Campus, I989), p. iा. 
simultaneously undermine state authority and ensure the survival of the movements' practitioners. For the Nōson Seinen Sha, cooperatist communalism was therefore a practical solution for revolutionary practice, which, for some members of the anarchist movement, might appear as much less heroic and idealistic than bombing the infrastructure or organizing the general strike to initiate revolution. Self-sufficient life and farming villages guided by mutual aid obviously does not overthrow the system overnight. It nevertheless undermines it radically by refusing the payment of taxes, dodging state repression, and living according to one's own needs. Anarchists' cooperatist communalism thus should not be dismissed as a mere naive, idealistic dream, but rather acknowledged as a very likely and thus practical solution in everyday life. Ultimately, despite its local and pragmatic focus, the Nōson Seinen Sha actually articulated universalist claims of liberation. Such universal practicality helped Japanese anarchists to position themselves against Japan's imperial state power as much as against Eurocentric hegemony, and their trans-imperial anarchism demonstrates anarchists' global vision in guiding revolutionary theory and practice. 